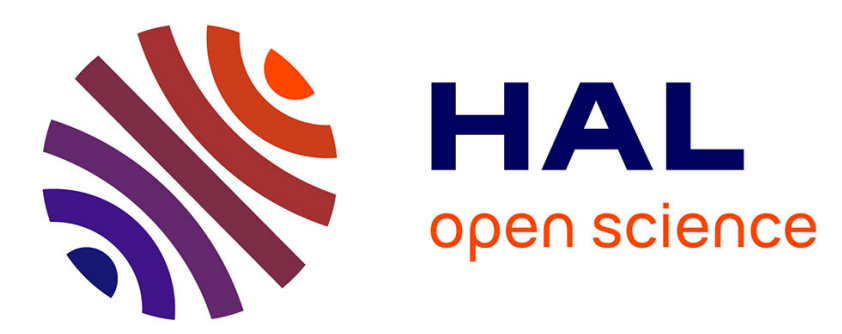

\title{
Sociologic Factors and Social Structure in Preparation of Tax Acts and The Assessment of Personal Income Tax in Terms Of Suitability to Social Structure
}

Ahmet $\mathrm{Ak}$

\section{- To cite this version:}

Ahmet Ak. Sociologic Factors and Social Structure in Preparation of Tax Acts and The Assessment of Personal Income Tax in Terms Of Suitability to Social Structure. International Journal of Tax Economics and Management, 2018, 1 (1), pp.22-36. 10.35935/tax/11.3622 . hal-02280384

\section{HAL Id: hal-02280384 \\ https://hal.science/hal-02280384}

Submitted on 6 Sep 2019

HAL is a multi-disciplinary open access archive for the deposit and dissemination of scientific research documents, whether they are published or not. The documents may come from teaching and research institutions in France or abroad, or from public or private research centers.
L'archive ouverte pluridisciplinaire HAL, est destinée au dépôt et à la diffusion de documents scientifiques de niveau recherche, publiés ou non, émanant des établissements d'enseignement et de recherche français ou étrangers, des laboratoires publics ou privés. 


\title{
Sociologic Factors and Social Structure in Preparation of Tax Acts and The Assessment of Personal Income Tax in Terms Of Suitability to Social Structure $^{1}$
}

\author{
Professor Dr. Ahmet AK \\ Department of Public Finance / Tax Law, \\ Ankara Haci Bayram Veli University Turkey \\ Email: ahmetak@gazi.edu.tr (Author of Correspondence) \\ Turkey
}

\begin{abstract}
Social state law has a need to regular fiscal source to maintain its sovereignty and to fulfill the duties the Constitution levies. Fort his reason, use of taxation power is a political obligation. The regulations related to tax concerns the whole society. Tax acts has a lot of features not included in other many acts. The most important one of these is that tax acts have to show a suitable change to the economic life altering constantly.
\end{abstract}

In every society, if the rules found or created are not suitable to expectations, necessities and conditions of a society in a specified time period, the society makes them out of order eventually whatever compeller power of them is inflexible and decisive.

While acts are prepared, it is compulsory to determine the real needs by observing the society studiously. Because tax acts have to be especially suitable to the fundamentals of moral and personal interest.

In legislating, changing or annulment of tax acts, it has to be cared social structure, market conditions, and suitability to menatlity and beliefs of the society rather than concrete or abstract reasons. Otherwise, even force or sanctions becomes insufficient in obeying the law.

In this study, it is aimed to search what sociologic factors are in legislation of acts and suitability of tax acts to social structure as is in other acts and to reveal tax acts by considering the regulations related to Turkish Personal Income Tax Act and literature review method is used as research method.

Keywors: Tax Law; Tax Acts; Social Structure and Taxes; Tax Law Designing; Tax Law Drafting; Income Tax.

\footnotetext{
${ }^{1}$ This study is derived from Ph.D. dissertation called "Tax Laws Drrafting and Legislative Process and Practise in Turkey" written by Ahmet Ak under the consultancy of Fethi Heper in Anadolu University Social Sciences Institute.
} 


\section{Introduction}

In contemporary states, three authorities -levying tax, right to use force, and right of coining Money- are given to the legal entities of states which are not given to natural persons. By means of these three authorities, state sovereignty or superior will of state is realized. States need fiscal resources to maintain its sovereignty. In terms of this, using taxation authority which means the legal and de facto power the state has in the subject of levying tax based on its sovereignty is a political obligation. The reason of this is that the state has to provide for the resources for the services expected by the state to relize by using taxation authority. [1]

Tax security of the citizens underlies significantly in the fundamental of democratic life and state structure. For this reason, the regulations -whether they are related to substantive tax law or tax dispute- concerning tax considerably draw everyone's attention.

Nowadays, social law state is emphasized in most of the countries' constitutions. That the state carries out the duties required by the principle of social law state requires the transfer of some resources created in private sector to the private sector, namely to the state. This is generally realized by the taxes.

Because tax is the most important tool applied to meet the expenditures required by public activities, it can be said that social (social state governed by the rule of law) law state is the tax state at the same time ${ }^{[2]}$.

In the general sense, tax can be defined as that tax is a tool providing income to state by transferring resources from private sector to public sector and it is a fiscal liability based on force and not based on reciprocity principle. ${ }^{[3]}$

Tax acts have some features not available included in other acts. Foremost among these, that tax acts follow all necessities of economic life changing rapidly and they show a change by obeying new conditions comes. Application of provisions put to obey the conditions of the time and the specified period requires a speciality.

States carry the duties required by the principle of socail law state social state governed by the rule of law out by taxes transferred from private sector to public sector.

Besides the qualities required by law state, legal fundamentals associated with taxation is determined by the constitution. The principle of seperation of power requires the acts prepared by legislative power to apply by the administration which is a part of executive power; requires administrative applications by judicial power to inspect if they exceed legal boundaries determined by acts and constitution.

\section{Law Norms and Their Social Validity}

If the rules created or found in every primitive or civilized society are not suitable to the expectations, necessity, and conditions of society a society in a specified time period, the society can destroy these rules 
Sociologic Factors and Social Structure in Preparation of Tax Acts and The Assessment of Personal Income Tax in Terms Of Suitability to Social Structure

eventually by disfunctioning and it does not matter whether the power of force of these rules are unpermissive and decisive. For this reason, preparation of acts and putting rules in the sense of creating law is a function needed a great importance and the people or associations carrying this function out has to watch the society studiously, determine the necessities in a realistic manner.

The scientific approach related to that constitutions binding political structure of the state over are social contracts have still been valid and it is an explanation emphasizing legality of constitutions. ${ }^{[4]}$

\section{The Aim of Acts}

While the acts are prepared for a various aims nowadays, one of the fundamental aims of all acts is to provide the stable development of society. The legal boundary of the force is drawn by the acts to provide social order and stable develpment. Acts encumber duties and responsibilities to persons and states, they intitle, they forbid some activities, they determine the power of administrative associations and some members and they regulate sanctions of the activities forbidden. ${ }^{[5]}$

While acts forbid some movements like murder, slander, parking in towaway zone, they put some liabilities such as paying tax. The persons not obeying the rules determined by the acts face some sanctions like limiting freedoms or paying a penalty by force.

The thought applying sanctions to the persons not obeying the rules determined by the acts is within the scope of that the people live more confidently. If the people live in a more confident way, they behave themselves better.

The second aim of the acts is to enable people to regulate their own lives. The acts guarantee the rights such as that people purchase and sell their goods voluntarily, establish a company and employ a worker. For these regulations, if necessary, the forces which the offical limit is drawn by the acts are realized by the state.

The third aim is to figure the debates related to what the act is and whether they are violated or not out.

When these three aims are examined, it seen that acts are not only included the definitions about what the forbidden acts are, but also they undertake the protection of personal interests. While some limitations are put by the acts, some guarantees are provided.

Determining what administrative system of the countries will be is a very important factor of the acts.

The phenomenon that the societies have been governed as independent states in last century have been increasingly evolved to that the societies are governed by international associations like in the example of European Union. Nevertheless, in consolidation of the acts, the states are still in charge centrally. These four aims form the fundamental of legal system. 
The constitutions regulate the management shape of the states, the responsibilities of the states towards their citizens and the responsibilities of the citizens towards the states. There are a lot of acts in the legal systems of the countries. However, besides that the acts are not contrary to each other, the acts have to be in an obvious harmony and integration. ${ }^{[6]}$ Being a lot of acts in the legal system creates wealth and opportunity source to the legists without providing a real benefit for the ordinary people. ${ }^{[6]}$

\section{The Relationship Among Act, Tradition-Morals and Personal Interests}

Act does not care the solutions of all problems related to the regulations of the relations of individualindividual, individual-state or the relations of these to other states or supranational associations.

Punishment and other sanctions can be generally effective in the application of the act in a short time period. It is compulsory to establish a structure based on the fundamental of tradition and personal interest in long term applications. For instance, the fear of catch is one of the most important factors in paying taxes.

Because tax acts are legislated to apply for years, they have to be suitable to the fundamental of morals and personal interests. Providing this can be possible in that most of the people think that contribution to the public expenditures are suitable to people's personal interests and morals approach. If most of the individuals think paying taxes are necessary for their interests, legal regulations related to what taxes are in the boundary determined and related to how much an individual has to pay tax can be placed.

In addition to these, punishments can be put for whom does not pay their taxes having the characteristics of contribution margin to public expenditures. Despite of this, it cannot be said that everyone pays taxes. A recreant group or a minor of taxpayers do not pay the tax or a part of whom does not pay tax will be caught and punished.

Besides that acts are established on morals thought and personal interests, they try moral thought to place in a way. The availability of an act persuades the people concerning what people need for their rights and interests. Tax acts are good examples for people to pay tax under the condition that tax acts compel other people being in the same position to pay their taxes. According to tax acts, that the provision which is collected by force when taxpayers do not pay their taxes figures provides people for obeying the act by paying tax. Because the people know that taxpayers who do not pay their taxes will be punished, the thought of justice is going to be protected.

Indeed, what the contribution will be is determined by the act even if the people think they need to cuntibute to the public expenditures. By this way, act and morals prop each other up. Morals is completed by act. Act gains strength when it is supported by only personal interest and the thought of morals. 
Sociologic Factors and Social Structure in Preparation of Tax Acts and The Assessment of Personal Income Tax in Terms Of Suitability to Social Structure

Şanver (1992) states that when tax acts are not moral, morals cannot be expected from the citizens and it gives citizens to evade tax. ${ }^{[7]}$ Akdoğan (1992) has a view that tax evasion becomes a tradition in Turkey and this tradition is may be created by tax acts. ${ }^{[8]}$

In modern states, three institutions play role in the subject of what the act is and how the act is determined. Legislative power (Parliament) legislates new acts, changes or cancels the old acts. Act drafts are legislated by legislative power. Ruling party is given an authority concerning doing regulations having less importance than the subjects required to legislate by legislation power. Courts fill the spaces in some legal regulations causing contradictive interpretations. Judicial decisions made up of case law $^{2}$. The legists think within the scope of these three official rules ${ }^{[6]}$ : Acts, the decisions of ruling party ${ }^{3}$ and judicial decisions.

\section{Social Factors Affecting The Preparation of Tax Acts}

In tax policy, income, wealth and expenditure taxes cannot be seen as fiscal tools providing income only for the state. While these taxes carry their fiscal functions out, they need to be suitable to social justice simultaneously. Income and wealth taxes need to procure tax justice that is distorted by expenditure taxes again.

In contemporary taxation, income and wealth taxes are needed to examine in terms of social aspect in addition to fiscal aspects of them and in some situations, the compulsory of use of wealth and expenditure taxes as a necessity of social state rises. ${ }^{[9]}$

In Constitution of Turkey Republic, it is stated that Turkey is a social law state (The Constitution of Turkey Republic, article 2). A lot of duties are levied to the state within the scope of this provision ${ }^{4}$.

As a necessity of social state law, the regulations are done in tax acts. The discount for the disabled included in personal income tax act, exception of vehicles - manufactured in a special manner and used by the disabled included in motor vehicle act- from motor vehicle act are the social aimed regulations. As theoretical, the taxes such as estate tax and inheritance and transfer tax are socail aimed taxes.

The target of changings realized in tax acts fort he social aims is naturally the regulations interested in individuals directly.

\section{Political Reasons Affecting The Preparation of Tax Acts}

One of the reasons that changes tax acts is the change realized by the ruling party for the vote anxiety. ${ }^{[10]}$ Ruling parties bring the regulations decreasing tax burden of people or some groups who vote for the ruling

\footnotetext{
${ }^{2}$ According to the principle of tax legality, judicial organs do not have any authority to fill spaces in the application of tax acts.

${ }^{3}$ Codes, instructions and circulars.

${ }^{4}$ Amongst the duties levied to the social state law within the scope of this, the followings can be ranked: the protection of family (article 41), Education right and duty (article 42), right and duty to labor (article 49), working condition and right to rest (article 50), article 56 and the regulations in following articles included under the title of health, environment and housing.
} 
party due to vote anxiety to the parliament. While the ruling parties decrease tax burden of the people affecting their vote potential, they can allege so-called concrete or abstract reasons.

We think that while tax amnesties are based on fiscal and technical reasons, they are also the typical examples of tax acts legislated for political reasons. ${ }^{[3]}$ Moreover, tax amnesty can rise as a secret reaction in the situation of high tax rates. ${ }^{[11]}$

\section{Fundamental Reasons Affecting Preparation of Tax Acts}

There are various reasons being a corollary to legislate new tax acts, to change or to dismantle tax acts available. We can state these under the titles of constitution changes, concrete and abstract reasons.

\subsection{Changing Constitutions and Tax Acts}

Because the principles and provisions related to the fundamental base of preparation of tax acts and legislative process are included in constitutions, fundamental reasons changing the provisions included in the constitution and concerning taxation firstly ought to be examined in preparation and legislation of tax acts.

According to the theory of generations developed by Thomas Jefferson in 1700s, possessions are benefitted by the living; not by the death. In other words, after the person has died, he/she loses his right and power on these possessions. Because giving a more importance to the will of old generations just for the reason of that they were birth previously cannot be possible, all the acts created by the will of the previous generation can be changed ${ }^{[12]}$. In this regard, adaptation of tax acts and constitutions including fundamental norms concerning taxation to changing social conditions is compulsory.

Natural legists try to examine the principle of determinedness of the constitution logically fort he protection of the rights obtained as a result of the struggle realized during the centuries by asserting that constitution is a kind of social contract. According to them, individuals have accepted social contract by consensus (by alliance). For this reason, socail contract -namely, the constitution- can be changed just by the same way. The practical result extracted from this thought giving the impression as if it were logical at first appearance is that the constitution is constant. Donnybrooks rose in the preparation of 1830 French Constitution and Alexis de Tocqueville protected the determinedness of the constitution by saying that "All the authorities of people, king and parliament are based on the constitution; these political powers are meaningless, but the constitution is exceptional". However, all these debates have stayed within the scope of the doctrine and determinedness principle in modern constitutions has been foreseen just for the shape of the state and some provisions having the qualification of superior legal rules ${ }^{[12]}$. The view that the constitution cannot be changed moves from the assumption that union of all individuals can be possible just within an abstract thought. While it is not easy to find an answer to the question "How do the people not merging for the change in the constitution merge in the acception of the constitution?", proving the availability of such kind 
Sociologic Factors and Social Structure in Preparation of Tax Acts and The Assessment of Personal Income Tax in Terms Of Suitability to Social Structure

of social contract is completely impossible. Fundamentally, the theory thatthe constitution is a kind of socail contract has been abandoned nowadays. ${ }^{[12]}$

While tax act text is being prepared, it can be expected that planning the future and fundamental bases are valid for a long time from the movement of necessities of the present time. However, to determine the direction of developments and changings especially in pluralist societies cannot always be possible. That's why, let that expecting tax acts last forever alone, even calculating how much some provisions of tax acts bear up can gradually be impossible.

From the perspective of thought that being tax acts suitable to nchanging conditions are compulsory, changing tax acts in time is inevitable.

\subsection{Abstract Reasons in Changing Tax Acts}

To change the tax acts, abstract reasons like that tax acts do not meet economic and social necessities, that they are not suitable to the realities of the country, that they do not enable more libertarian democracy and tax amnesty, and that they do not realize economic and social development can be alleged. It is possible that these reasons can be increased until the last limit of the human mind at thate of the speculative abilities of the people alleging these reasons. These reasons are generally suggested by political parties or pressure groups to mold public opinion in the terms which some changings in tax acts are seen as necessary. The persons knowing that instead of concrete reasons, abstract mold repeated frequently and exactly are more effective on large mass of people by benefiting from this weak aspect of mass psychology can prepare a suitable environment for the changes in tax acts they allege they are necessary.

It means that concrete reasons are alleged if tax acts foreseen to realize are based on the asserts seen as logical instead of the data revealing as a result of analysis of some economic and social processes in terms of scientific aspect.

\subsection{Concrete Reasons in Changing Concrete Reasons}

As a result of scientific studies realized studiously, if a real link is proven between changing in tax acts suggested and obvious necessities, it means that there are concrete reasons. Nevertheless, concrete reasons are determined without application lying art by numbers.

In this regard, an availability of casual relation and efficiency degree of this relation ought to be proven in terms of scientific aspect between changing in tax acts suggested and economic and social result to mention concrete reasons. Moreover, reached results have strained from the critics made in public openly.

\subsection{Inconsistency Between Social Structure and Tax Acts}


As is in constitution and all other acts, because the rules forming tax acts are stable while social structure is in a changing process, It is usual to find an inconsistency between social structure and tax acts. However, this Notion of inconsistency are not understood as a contrary between tax acts-society or society-state.

Every society has idiosyncratic economic, social and political structure. Social structure is permanently in state of flux dependent upon time. While these changes ocur fast in some societies, these occur slowly in other societies. This situation is under the effect of that the society can be traditional society, transitional society or modern society. Because tax system also called as an alliance of tax acts forms a part of social structure, changes in social structure cause tax acts to alter by showing their effects on tax structure. ${ }^{[13]}$

Tax structures ${ }^{5}$ rise as a historical institution dependent on economic, social and politic conditions of the countries. Tax acts included in tax structures are needed to accord to changes in economic and social structure. For any country, there is no possibility to be tax acts protecting topicality and being valid always. Even if making seperations as society-state or society-tax acts due to this procedural reason and to explain some processes better are suitable to the aim, it is not possible to allege that there is an exact contrary between them. The reason of this is that the aim of the acts generally consists of regulating between peoplepeople or people-state suitable to social necessities. Nevertheless, social life that are open every kind of social, political and aconomic effects or developments and that rises these changes quite fast especially in contemporary plüralist societies. Owing to this phenomenon, tax acts cannot react these changes in a short time. Legal regulations realized in the areas especially economic and technologic developments affect directly can become old even in the short time that includes the time from legislative power to being valid. On the other hand, this opennes between social life and tax acts are explicit in the area of public law because the opennes includes a changeable and dynamic social reality.

Nevertheless, public can be effective in the preparation of acts concerning public law including tax acts. [14]

Law history researches show that the institutions of public law have undergone more changes than the institutions of private law within the boundaries of broad time zones and civilization. ${ }^{\text {[12] }}$

\section{Providing Participation of People to Legislative Process}

Participation of people to legislation process is needed to provide to understand tax acts better by people and especially to adopt the act. As a fundamental process of legal system, everyone is assumed to know the acts and not knowing the acts cannot be accepted as an excuse. That people are responsible just fort he

\footnotetext{
${ }^{5}$ All the tax sets that individuals and corporations are liable to pay in specified period are called as tax system or tax structure (For the details see: Heper, 1981: 17).
} 
Sociologic Factors and Social Structure in Preparation of Tax Acts and The Assessment of Personal Income Tax in Terms Of Suitability to Social Structure

acts they know becomes impossible for the state to carry its functions out. However, the state cannot play out in that everyone has to know the act and not knowing the act cannot be accepted as an excuse.

If there is no his principle, the possibility of application of the act disappears and this causes legal system to distort due to the fact that even the persons having quality to search what the provisions of the act are.

Because that acts are updated suitable to the necessities of the day and that the reliability of the acts officially is parovided by the state are accepted, the acts are needed to publish by the state by printing. ${ }^{[15]}$

Moreover, law-makers provide the availability of the acts and reaching people to this for its citizens. The reason of this is that the state needs its citizens to know their rights and responsibilities.

Because people participate to legislation process by selecting their representatives nad via their respresentatives and by this way they take part in democratic process, functioning democracy is provided completely.

People's access to legislation can be divided into two categories: Physical participation and access in terms of being understandable. Physical access means that people access the acts after the acts are printed and copied. There are a lot of methods in providing physical access particularly the way of internet.

Access in terms of being understandable is to provide people for understanding the act when they obtain. $[15] 6$

By explaining the works about the act to the people, opening the draft to the ordinar citizens needing and related persons provides the changes in important parts for doing in a more qualifed manner. In addition, this work benefits for the parliament members, legists and other people including in the legislation process to understand the important changes.

Providing participation of people to the legislation process gives a benefit in that it can be seen the possible effect of the act as if it were legislated from now on. Besides this, the effect of this change supported can be seen easily before coming to the parliament. In terms of this, Political consultants and legists have important ontributions to development of act suggestion and providing draft forming.

\subsection{Transparency and Being Understandable in Tax Acts}

\footnotetext{
${ }^{6}$ Approximatel 20 answers have been received from the firms in Australia and New Zealand within the scope of the modernization Project realized to provide people's participation to legislation process via free internet mediation. The Project of People's Participation to Legislation Process includes the following projects:

- The availability of legislation in electronic environment and maintaining the possibility being by people as printed publication,

- Providing people's access to electronic and printed shape of the act after the act is legislated,

- Providing people's participation to legislation process or the process the regulation is done,

- Providing people's participation after the change in the act is prepared,

- Providing electronic participation in parliament process and in important processes of draft,

- $\quad$ Providing free electronic access to drafts, offers and regulations by means of internet.
} 
Act provisions should be understandable by the persons expected to obey out of the special events or the special situations included in them can be seen. Moreover, they ought to be consistent and they cannot be changed quickly so that thay can be learnt and followed. ${ }^{[16]}$

Users and executives of the acts legislated are generally legists and specialists; but act draft should be understandable by politicans because most of the politicians are not legists or specialists. ${ }^{[14]}$

Using words and idiooms demoded in the language of the act, meaningless repetitions, hardly understandable statements, the structure and indirect syntax in the statements of the act are subjects of criticism. Even though the act is applied to the ordinary people, the interpretation of tha acts is realized by consultants, accountants, lawyers or judges.

Irrevocable compulsory tools of the language are acuuracy, opennes, trueness, and complete extensity in specialized societies. According to the non-specialized societies, however, this situation is a tactic exactly to augments solidarity among the individuals in specialized societies and to protect the siginificant difference between the specialized societies and non-specialized societies. That's why, this situation is seen as meaningless words, verbal one-upmanship, using excessive words, placing tortuous and shoddy words by non-specialized societies. The true of the matter, acts are not towards people and the group of specialists; rather, they should be between them and be in a language structure the groups of specialists can teach to ordinary people easily. ${ }^{[17]}$

If tax acts are prepared shortly, using words in act provision will have an open aim and unnnecessary word will not be used. That aims and policies of law makers can be understand easier can be provided by preparing a more attentive act draft. ${ }^{[18]}$ For instance, before the act is legislated, the person preparing the draft can take notes the details including the different parts of the act and not connected the links among them. By this way, it can be provided that these can be linked and the provisions contrary to each other can be harmonized by seeing these before. This situation is an example of the close relationship between draft process and policy development.

The necessity of being the acts short does not mean that the act prepared shortly is better than the act prepared long. In the place required detailed explanation, it cannot be avoided to account for the details by thinking that the act becomes short.

Because the statement of an idea is made by less numbers of words it will be core and understandable and it will be avoided being excessive as a result of just a careful work. The words that do not have any function cannot be included in the act draft. How long an obvious tax act will be an interesting philosophical problem and in addition to this, it is an important subject in preparartion of tax draft. Taxation is the last phenomenon suitable to market economy in transition countries. In such kind of countries, experiences are expected to 
Sociologic Factors and Social Structure in Preparation of Tax Acts and The Assessment of Personal Income Tax in Terms Of Suitability to Social Structure

increase with the length of tax acts and prevailing taxation. Beginning tax legislation process newly is a problem causing complexity. ${ }^{[18]}$

Reasons, definitions and explanations are not included in the act rules. The inclusion of the act articles should be compatible and understandable for the readers and it ought to be written as a simple language. A used word should not be used again in the same sentence as possible as and the subject desired to tell should be explained easily and directly. Being tax acts as understandable and open makes easier for judges to understand the reasons of legislation of acts. ${ }^{[19]}$

If the provisions of an act can be easily understood by the reader, it can be said that this act is transparent. Beginning to state the aim of the act is a way of providing transparency ${ }^{7}$. On the other hand, the provisions prepared by a broad general expressions can cause some problems (e.g., beginning personal income tax act with a statement of "This act is taxed the incomes"). Because that the act can be applied and is legislated obviously makes the interpretation of the implicit provisions easier as suitable to the function determined within the scope of the aim of the act, it can be more benefit.

However, legislation of an act by cancelling general provision concerning the aim of the law maker in terms of taxation can be dangerous because courts can interpret the provisions of the act in terms of the aim of the law makers. If there is no aim of the act, courts can make faulty interpretations.

Avoiding wrong expression of the aim in tax acts creates a different difficulty because while tax acts do not include the situations quite technical and whcih provisions are concrete in every event, some regulations can include possible transaction and taxation subjects. ${ }^{[\mathbf{1 8 , 1 9 , 2 0}]}$

Act draft is limited as that fundamental points of policy is permitted to debate. If some provisions are embedded to surprise with verbiage, parliament members have difficulty to perceive what fundamental points are and the places that should be debated. ${ }^{[14]}$ The language of the act should not cause objections and prosaism should become routinised. In practice, it is seen that the shapes full of traditional, frequent and unnecessary are choosen. While prepared act draft, it is needed to accept "the used is the best experience" instead of Bennion's say "the experienced is the best". [21]

The compexity of tax acts causes tax administration liable to administer these to have more difficulties. However, the complexity of tax acts cannot be avoided for some reasons. [9]

The complexity of tax acts causes tax administration to be in a can of worms and it creates some difficulties in teaching to the people getting education on this field. ${ }^{[8]}$

\subsection{The Language Problem}

\footnotetext{
${ }^{7}$ A tax act including regulations concerning the aim of tax act in Turkish Tax System is not met.
} 
That the language of the tax acts is complex is revived frequently by public opinion. Including tax administration, most of the people accept this situation. Nevertheless, the complexity of the language of tax acts is not fault of present generation, previous generation or the generation preparing the act. Tax acts are not the acts applied in a short term and they consist of a hundreds of articles and they are the acts having a whole in itself. While any article of the act is changed, use of current language can cause an inconsistency in itself and it can pull of the connection with other acts. For this reason, if tax acts is started over, language of the act is provided to be simple and understandable. Yet, starting the tax acts over is not a simple situation. ${ }^{[22]}$

In general, the language of the tax act used is implicit or inapprehensible, complex, difficult to understand and its meaning is not certain. That tax acts is not a structure that is understandable for everyone is one of the reasons causing taxpayers to evade tax. ${ }^{[22,23]}$

The Statute Law Society in England criticized the language of the act because the details included in act provisions are prepared in an inflexible manner and to determine the meaning degree of the circumloutious provisions generally not understandable or implicit and to figüre the meaning of them out specialized people are needed.

In preparation of tax acts, the words generally used and given the same meaning by everyone ought to be selected for everyone to be understandable. The written text should be prepared in terms of vernacular in the time it is written and it should not be used in different meanings from common tongue. The used words should be applied both for the singular and the plural; the words representing the plural should include the singular; they should imply both men and women they should be used in continuous time but state future time at the same time ${ }^{[24]}$, the word of "person" should include bot natural person and legal person, a word should have just a one meaning, and if necessary the word telling a situation used in the dictionary best has to be used.

Because punctuation marks can change the meaning of the text, it is used carefully and grammar rules should be cared ${ }^{[22]}$.

When examining tax acts in Turkey, it is seen that there are words and sentences which lecturers of public finance have difficulties to transfer the related information to their students. Akdoğan (1992) states that it is impossible to give message to the students like the statements "the precautions against of current detriments" included in corporate income tax act ${ }^{[8]}$.

\section{Conclusion}

The most important point that distinguishes tax laws from other laws is the tax law regulations concerning the large population. Tax regulations tax regulations have a vital importent everyone. The ability to fulfill the duties required by the principle of social state governed by the rule of law requires the transfer of some of the resources created in 
Sociologic Factors and Social Structure in Preparation of Tax Acts and The Assessment of Personal Income Tax in Terms Of Suitability to Social Structure

the private sector to the public sector, that is the state. This happens in general via taxes. Taxes are the most important means of financing expenditures required by public activities, therefor it can be said that the social state governed by the rule of law is also a tax state.

Tax laws change rapidly by following all the requirements of the changing economic life and adapting to new conditions. Since tax laws have been enacted for many years to be applied, they must be in accordance with morality and personal interests. This can be achieved by the fact that most people think that contributing to public expenditure is appropriate for their own interests and morality.

If the majority of individuals consider that tax payments are necessary for their own interests, legal arrangements can be placed on what the taxes are within the defined limits and how much each person should pay. Laws are based on moral thought and self-interest, but also try to place moral thinking in a template. The existence of a law can convince people of what they need for their rights and interests. Even if people really think that they should contribute to public spending, what this contribution will be determined by law. Thus, the law and moral thought support each other. Morality is completed by law. The law can only be strengthened if it is supported by self-interest and moral thought.

In contemporary taxation, the financial aspect of income and wealth taxes, taking into account the social aspect, income, wealth and expenditure taxes in some cases as a requirement of the state of social state governed by the rule of law to be used directly for social purposes. The enactment of new tax laws, particularly for constitutional amendments, for political reasons or for abstract or concrete reasons, is the basic justifications for changing or abolishing existing tax laws.

However, in order to amend the tax laws, abstract reasons can be asserted like it does not meet the economic and social needs, does not comply with the realities of the country, does not allow for a more liberal democracy and tax peace, and cannot realize economic and social development. Tax laws are inevitable to change in due time considering the fact that the necessity of adopting to changing conditions.

Nevertheless, this change should be appropriate to the social, economic and political structure of each society. Changes in the social structure ocur faster in some societies, but appear more slowly in some societies. This is due to the fact that societies are traditional society, transitional society or modern society. Public participation in the legislative process is essential to better understand the tax laws and the adoption of the law. As the basic principle of the legal system, everyone is assumed to know the laws and it is not an excuse not to know the law. The fact that people are only held responsible for violating the laws of which they have real knowledge will make it impossible for the state to perform its functions.

While preparing the laws, in addition to the analytical and comparative methods, sociological examinations should be made. The methods that will make the provisions of the law effective should be investigated. In particular, the constitution and tax laws must reflect the lifestyle and philosophy of the people, not the idea of a certain group of intellectuals. From a sociological point of view, the lawful preparation of a law, its discussion and its adoptation in parliament, ie its enactment, does not mean the adoption of the law. The main expectation is the acceptation and adoption of the law by public. 
The main force of the laws is the fear of sanctions. As the laws are new, the legislator will be more interested in the implementation of the law and will have more power and impact.

Laws should be in accordance with the geographical location of the country, climate, soil structure, the way of life of the people, the degree of freedom that the constitution can withstand, religious beliefs, traditions, wealth, commercial life and moral structure.

Even if the principles of country management are avoided, even the best laws that have been effectively implemented in time will begin to operate against the state. In governance based on strong principles, the power of the principles will ensure that even the bad laws are good. Laws are guided by society and in a sense laws become guidlines for society. Even for the most perfect laws to be prepared, it is necessary to accustom the minds of those who will be applied to them before putting them into practice.

\section{References}

1. Ak, A. (1999). GVK. Açisindan Vergi İdaresi ile Vergi Yargisi Arasindaki Yorum Farkliliklari ve Vergi Yargisi Kararlarinin Vergi İdaresi Üzerindeki Etkileri. Unpublished Master Thesis. Eskişehir: Anadolu Üniversitesi Sosyal Bilimler Enstitüsü.

2. Kaneti, S. (1986/1987). Vergi Hukuku. İstanbul: Özden Kardeşler Matbaasi.

3. Turhan, S. (1993). Vergi Teorisi ve Politikasi. İstanbul: Filiz Kitabevi.

4. Karabatak, R. (1998). Türk Hukukunda Yasalarin Anayasaya Uygun Yorumu. Daniştay Dergisi, 28(94), pp. 28-48.

5. Gibbons, J. (Editor) (1994) Language and the Law. London and New York: Pearson Education\& Longman.

6. Honore, T. (1995) About Law. Oxford: An Introduction, Clarendon Press.

7. Şanver, S. (1992). VIII. Türkiye Maliye Sempozyumu, Türkiye'de Vergileme Sorunlari ve Ekonomik Istikrar, Bursa.

8. Akdoğan, A. (1992). VIII. Türkiye Maliye Sempozyumu, Türkiye’de Vergileme Sorunlari ve Ekonomik Istikrar, Bursa.

9. McGee, R.W. (1997) "Some Principles of Taxation For Latin America": Lessons From The USA and European Experiences, Presented at the 14th Conference of the Business Association of Latin American Studies, Rio de Jenerio, Brazil.

10. Domaniç. H. (2001). Vergi Kanunlarinin Yapiminda ve Uygulanmasinda Hatalar. Prof. Dr. Erdoğan Moroğlu'na 65. Yaş Günü Armağani, İstanbul: Beta Yayinevi.

11. Tüğen, K. (1992) VIII. Türkiye Maliye Sempozyumu, Türkiye'de Vergileme Sorunlari ve Ekonomik İstikrar, Bursa.

12. San, C. (1981). Anayasa Değişiklikleri ve Anayasa Gelişmeleri. Ankara: Toplum Bilimleri Araştirma Merkezi Yayini. 
Sociologic Factors and Social Structure in Preparation of Tax Acts and The Assessment of Personal Income Tax in Terms Of Suitability to Social Structure

13. Heper, F. (1981). Toplumsal Yapi ile Vergi Yapilari Arasindaki İlişkiler. Eskişehir: Türk Vergi Yapisina İlişkin İstatistiki Bir Model Denemesi, 1950-1971.

14. Zander, M. (1999). The Law-Making Process. (5 $5^{\text {th }}$ Edition). London/ Edinburgh Dublin: Butterworths.

15. Lawn, M. (2001). Improving Public Access to Legislation. A speech for presentation to a conference on Public Law. New Zealand: Duxton Hotel.

16. Radin, M.J. (1993) Reconsidering The Rule of Law. Ed: Frederick Schauer, within Law and Language, (p. 273-312), New York: New York University Press.

17. Vijay, B. L. (1994). Cognitive Structuring in Legislative Provisions. John Gibbons (Ed.), within Language and The Law, (p. 136-155), London and New York: Routledge Taylor\& Francis Group.

18. Thuronyi, V. (1996). Drafting Tax Legislation. Victor Thuronyi (Ed.), within Tax Law Design and Drafting Volume I, (p. 71-94), USA: IMF.

19. Gordon, R. K. \& Thuronyi, V. (1996). Tax Legislative Process. Victor Thuronyi (Ed.), within Tax Law Design and Drafting Volume I, (p. 1-14), USA: IMF.

20. Vanistandael, F. (1996). Legal Framework for Taxation. Victor Thuronyi (Ed.), within Tax Law Design and Drafting Volume I, (p. 15-70), USA: IMF.

21. Akyürek, A. (1992). ABD’de Hukuki Yazim Tekniği ve Kanun Tasarilarinin Hazirlanmasi. Amme Idaresi Dergisi, 25 (2).

22. Tufan, A. (1991). Vergi Yönetimi ve Yargi İlişkileri Paneli. Maliye Bakanliği Gelirler Genel Müdürlüğü Yayini, Ankara.

23. Franzoni, L.A. (1999). Tax Evasion And Tax Compliance. N.6020, Bologna-Italy.

24. Yerci, C. (1991). Vergi Kaçirma Sorunu ve Soruna Karşi Avrupa Topluluğundaki Uygulamalar. Ankara: Ankara Üniversitesi, AT Araştirma ve Uygulama Merkezi, Uzmanlik Tezi.

\section{Author Details}

Dr Ahmet AK is a professor of Faculty of Economics and Administrative Sciences Department of Finance, Ankara Haci Bayram Veli University. He received his Ph.D. Anadolu University (Public Finance/Tax Law) Eskişehir, 2004 (Ph.D. Dissertation, Tax Law Drafting Legislation Process and Practice in Turkey). He is very interested in research mostly on Social Science and Humanities, Public finance, Taxation \&Tax Law, Religious Studies (especially Islamic finance). Ahmet AK is working with various reputed journals as editor, co-editor and reviewer. 